\title{
Mercury content in the superficial geological formations of Hungary
}

\author{
Ubul Fügedi, József Vatai, László Kuti \\ Geological Institute of Hungary, Budapest
}

\begin{abstract}
Among the periodic system's elements, mercury $(\mathrm{Hg})$ is most liable to dispersion and, simultaneously, most liable to secondary enrichment. Consequently, mercury enrichments can occur as a result of a number of geologic as well as anthropogenic processes. If the geologic processes cease, quite extended dispersion halos can form around a former accumulation center.

Hydrothermal mineralization is a typical process giving rise to mercury concentration. As a result, regional mercury impacts can occur in the floodplains of rivers flowing from the mining and heavy industrial regions of Transylvania and Slovakia. Elsewhere, mercury anomalies detectable at the intermediate scale $(1: 50,000)$ can be found in the Zemplén and Mátra Mountains and, subordinately, in the Börzsöny Mountains. Typically mercury anomalies develop above major structural lineaments as well, unless they are buried under thick young sediments. A remarkable example is the deep fault separating the Pilis and Visegrád Mountains. Another group of $\mathrm{Hg}$ anomalies is caused by wellknown mercury contamination sources (Kazincbarcika, Balatonfüzfő), which are truly local: they cannot be detected at the scale of the given study.
\end{abstract}

Key words: mercury, geochemical anomalies, background, Hungary, regional anomalies,

Transylvania, mineral exploration, contamination

\section{Introduction: Mercury in the Earth's crust}

Mercury is typically a microelement: its Clark value in the Earth's crust is $56 \mu \mathrm{g} / \mathrm{kg}$ (Wedepohl 1995). Newer sources quote higher crustal Hg concentration $(80 \mu \mathrm{g} / \mathrm{kg}$ - Risher 2003; $67 \mu \mathrm{g} / \mathrm{kg}$ - WebElements, 2010). It is characterized by a dual geochemical behavior: it is liable to extreme concentration and to dispersion,

Addresses: U. Fügedi, L. Kuti, J. Vatai: H-1143 Budapest, Stefánia út 14, Hungary e-mail: fugedi@mafi hu

Received: March 7, 2010; accepted: May 13, 2010 
the latter resulting in an approximately entirely even concentration. Its ability for concentration can clearly be characterized by the ratio of the threshold of its economic ability to be mined (in large occurrences) to its crustal average value, which is presented for comparison with some other elements in Table 1.

Its ability for dispersion is clearly manifested by the fact that mercury is the second most equally dispersed element (of lowest variance) after oxygen in the

Table 1

Global lithosphere baselines (b) and approximate workabke concentrations (wc) of some elements

\begin{tabular}{|l|l|l|l|}
\hline Element & $\mathrm{b}^{*}$ & $\mathrm{wc}^{\star *}$ & $\mathrm{wc} / \mathrm{b}$ \\
\hline Iron $(\%)$ & 6,3 & 30 & 4,8 \\
\hline Nickel $(\mathrm{mg} / \mathrm{kg})$ & 90 & 6000 & 67 \\
\hline Copper $(\mathrm{mg} / \mathrm{kg})$ & 68 & 5000 & 74 \\
\hline Zink $(\mathrm{mg} / \mathrm{kg})$ & 79 & 20000 & 250 \\
\hline Arsenic $(\mathrm{mg} / \mathrm{kg})$ & 2,1 & 50000 & 24000 \\
\hline Mercury $(\mathrm{mg} / \mathrm{kg})$ & 67 & 5000000 & 75000 \\
\hline
\end{tabular}

* WebElements, 2010

** Magakyan, 1974

the mercury in the Earth's crust occurs in the elementary state and a substantial majority thereof is in capillary water (Fursov 1977). The main reason for mercury's geologic mobility is that its tension largely exceeds that of the other metals.

If the geologic processes inducing its enrichment cease, the combination of its concentration and dispersion results in the dispersion of the concentrated mercury, giving rise to extended geochemical anomalies around its accumulations. Given that mercury is enriched by an extremely wide variety of geologic processes, from the formation of hydrocarbon to hydrothermal mineral occurrences, it can be regarded as a universal geochemical indicator of young geologic effects (Saukov 1946); its dispersion halos are more extensive than those of any other element (Sergeev 1957).

In its industrial applications mercury is predominantly used in the
Earth's crust in Cretaceous and preCretaceous sequences, irrespective of their age and lithology (Fursov 1983). Its expected concentration in rocks of different age and composition (Table 2) shows hardly any variation commonly with slightly lower values in carbonate than in silicate rocks.

The strong dispersion ability of mercury is due to the reduction of its compounds to metal mercury, which is a rather slow process discernable only on a geologic scale. More than $80 \%$ of

\section{Table 2}

Median mercury concentrations $(\mu \mathrm{g} / \mathrm{kg})$ in some rock types (Fursov 1983)

\begin{tabular}{|l|l|}
\hline Granite, granodiorite & 67 \\
\hline Diorite & 67 \\
\hline Gabbro & 75 \\
\hline Ultrabasic rocks & 65 \\
\hline Rhyolite & 54 \\
\hline Andesite & 51 \\
\hline Basalt & 51 \\
\hline Marble & 42 \\
\hline Quartzite & 94 \\
\hline Clay & 91 \\
\hline Siltstone & 66 \\
\hline Sand, sandstone & 74 \\
\hline Gravel and conglomerate & 70 \\
\hline Limestone & 52 \\
\hline Dolomite & 37 \\
\hline
\end{tabular}


elementary state. For this reason dispersion halos in the vicinity of industrial mercury contamination sources are very limited, much more so than around any geogenic source (Smith and Smith 1972; Yanin 1997; Ping et al. 2008; etc.). The dispersion halos formed in the gaseous phase within the soil feature the highest contrasts (Fursov 1983). Unfortunately, appropriate equipment for their study is lacking in Hungary. However, during the last 20 years it was possible to obtain enough quality analyses from near-surface sediment samples to appraise the mercury content of these geologic formations and to detect mercury accumulation and contamination at different scales. Based on these data we can attempt to characterize the main distribution patterns and natural variation of mercury in the surficial geologic formations of Hungary. In the present paper we summarize the results of our geochemical investigations completed in this period.

\section{Analyses}

Until 1997 the cold-vapor AAS method (Bertalan and Bartha 1999) was used for the analysis of mercury after leaching with hot aqua regia in Teflon bombs. Since 1998 the determination of total mercury has been carried out using a cold vapor atomic absorption technique, involving pre-concentration on a gold amalgam before detection with an "Advanced Mercury Analyser" (AMA-254, ALTEC) instrument (Sandström et al. 2005). The analysis was performed directly on solid samples without any sample preparation. Mercury is liberated from the sample during a programmed temperature elevation to $850{ }^{\circ} \mathrm{C}$ and amalgamated with gold. Mercury vapor is then released from the amalgam by heating and detected using atomic absorption spectrometry. The detection limit of the atomic absorption method is $30 \mu \mathrm{g} / \mathrm{kg}$ and the detection limit with the AMA-254 is 0.1 $\mu \mathrm{g} / \mathrm{kg}$.

\section{Background and anomalies}

Neither the terms background nor anomaly are well defined. As Reimann and Garrett (2005) have shown more than 10 quite different definitions are in use in the scientific literature. The Hungarian rule of law (10/2000., 219/2004.) and most of the EU documents (for example EU, 2008) in various forms define the background of some component as its "natural" concentration(s) without (any) anthropogenic influence.

In directly opposition to this conception, in our opinion (Fügedi et al. 2006) there is no reason to estimate where geochemical cycles of individual atoms have been influenced by any human activities, and where activities considered as "natural" end and the "anthropogenic" influences begin. Our (purely technical, i.e. formal) conception is that background and anomalies need to be viewed together, and can only be defined on the basis of statistical distribution patterns, 
always taking, however, the possible heterogeneity of the background (geologicgeographical setting) into account.

There exist a number of different techniques for the statistical calculation of the background (see Reimann et al. 2005). In our experience the most effective method is the separation of the so-called "uncorrelated background" from the well-correlated anomalies. In presenting the results of some technical problems in this paper we followed another method: the background of mercury always falls into the same range (between two frequency minimums of the polymodal distribution), in which the majority of the values occur. The positive and negative anomalies are placed outside of this range. If the distribution is unimodal, all samples may be considered as background.

It is important to point out that the background is, in most cases, heterogenic: the concentration may be quite different in different rock types. The variability (the range of the background concentrations) is dependent on the location of the sample type: e.g. overbank sediments represent a larger catchment basin (with lower variability) than stream sediments, while stream sediment samples represent larger territories than a soil sample.

\section{Previous investigations}

1. Continental scale. In the FOREGS Geochemical Baseline Mapping Programme (Salminen et al. 2005) 14 overbank sediment and 14 stream sediment samples were collected from Hungary. All the solid samples of this program were analyzed for mercury in the laboratory of MÁFI using a AMA 254 instrument.

2. Regional scale (Darnley et al. 1995) geochemical mapping (1: 500 000) in Hungary was completed in 1991-1995 (Ódor et al. 1997, 1998). In regions with well-developed drainage systems, 196 catchment basins of approx. $400 \mathrm{~km}^{2}$ were delineated and flood-plain (overbank) deposits sampled at their outlets. Two samples were collected at each site, one from a depth of 0 to $10 \mathrm{~cm}$ and one from 50 to $60 \mathrm{~cm}$. The most important result of these investigations was that in Hungary there is no single background because the territory is divided into four geochemical regions (Fig. 1) with different characteristics. The larger part of the country (the "main" Region 1) does not show a characteristic association of elements, i.e. the dominant part of the variations resulted from processes of accumulation and leaching. In Central Hungary (the "limy" Region 2) the association of Ca-Mg-Sr- $\mathrm{CO}_{3}{ }^{2-}-\mathrm{PO}_{4}{ }^{3-}-\mathrm{SO}_{4}{ }^{2-}$ reflects the presence of limy soils. Near the western border line (the "ferrous" Region 3) the iron alloy metals $\mathrm{Co}-\mathrm{Cr}$ $\mathrm{Ni}-\mathrm{Fe}$ originate from basic and ultrabasic rocks of the Alpine belt. In the floodplain deposits of rivers discharging from Transylvanian mining areas and from some heavy industrial centers ("eastern" Region 4) we can find characteristic Ag$\mathrm{Au}-\mathrm{Cd}-\mathrm{Pb}-(\mathrm{Cu}-\mathrm{Zn})$ anomalies in the overbank sediments of lower courses, and also $\mathrm{Hg}$ originates from the processing of ore from low- to medium-temperature hydrothermal ore deposits. 
Fig. 1



Geochemical regions of Hungary (after Ódor et al. 1997, corrected). 1. Region 1 ("main"), 2. Region 2 ("limy"), 3. Region 3 ("ferrous"), 4. Region 4 ("eastern"), 5. catchment area in Hungary, 6. catchment area outside the national boundaries

On the mercury distribution map (Fig. 2) yet another tendency is visible. More variable $\mathrm{Hg}$ concentrations occur in the mountainous areas than in the plains. The reason for this is that during the weathering process mercury vaporizes and precipitates continuously, and that during transportation the concentrations become more and more equalized.

3. Intermediate scale (1:50 000): In addition to the surveys mentioned above, a large part of the hilly and mountainous regions of Hungary was subjected to more detailed geochemical mapping, based on stream sediment sampling of small, approx. $4 \mathrm{~km}^{2}$ catchment basins (Hartikainen et al. 1992; Ódor et al. 1999; etc.) between 1989 and 1998. The most important result of these investigations was that no significant difference between the composition of stream and overbank sediments eroded from carbonatic, volcanic and siliciclastic rocks were found (Fügedi et al. 2007). The concentrations of elements are mainly determined by the young (Miocene-Holocene), easily eroded, soil-forming sediments (tuffs, loess, etc.). Against this background only the influence of rare, extreme geologic formations becomes visible: some ore deposits, alkaline ultrabasic rocks, etc. (Fügedi et al. 2006). Therefore, in 2000-2010, most of the detected anomalies were resampled.

The results of these three mapping programs were integrated in 2008-2010. Now the uniform database contains 1,863 records with 1,629 mercury analyses. 


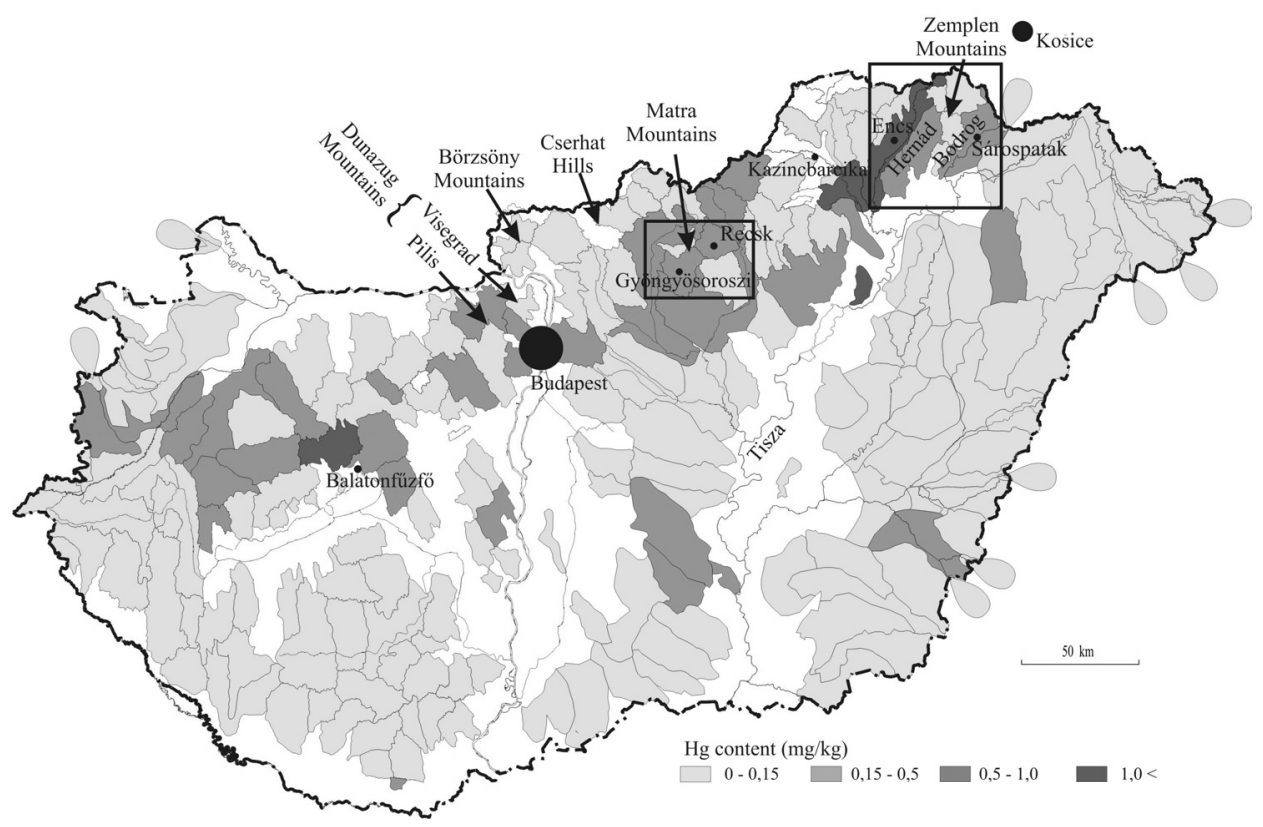

Fig. 2

Mercury background concentrations in Hungary based on overbank sediments

Some parts of the integrated geochemical atlas of Hungary (Figs 3, 4) are published for the first time in this paper.

The most important (recent) mercury contamination sources in Hungary were described in the NATO ASI Programme "Regional and Global Mercury Cycles: Sources, Fluxes and Mass Balances", in 1995-1996. A large contamination (about $600 \mathrm{t} \mathrm{Hg}$ ) was located at Kazincbarcika resulting from the production of hydrochloric acid. A second is located at Balatonfúzfó close to the Nitrochemistry Works (Fügedi et al. 1995, 1996). Unusually high values of $\mathrm{Hg}$ with a limited geographical extent were detected in the Budapest agglomeration area. Such very local $\mathrm{Hg}$ contamination sites remain difficult to detect with traditional geochemical mapping methods.

\section{The regular content of mercury in Hungary}

The background levels of mercury (Table 3) in the geochemical regions of Hungary have been determined within the framework of completing the 1:500,000 geochemical atlas of Hungary.

In full compliance with the above presented features of mercury its expected values are almost equal in the geochemical regions, notwithstanding substantial differences in geology. The exception is the eastern Region 4 with 1.5-4 times higher Hg-values than elsewhere in the country. 


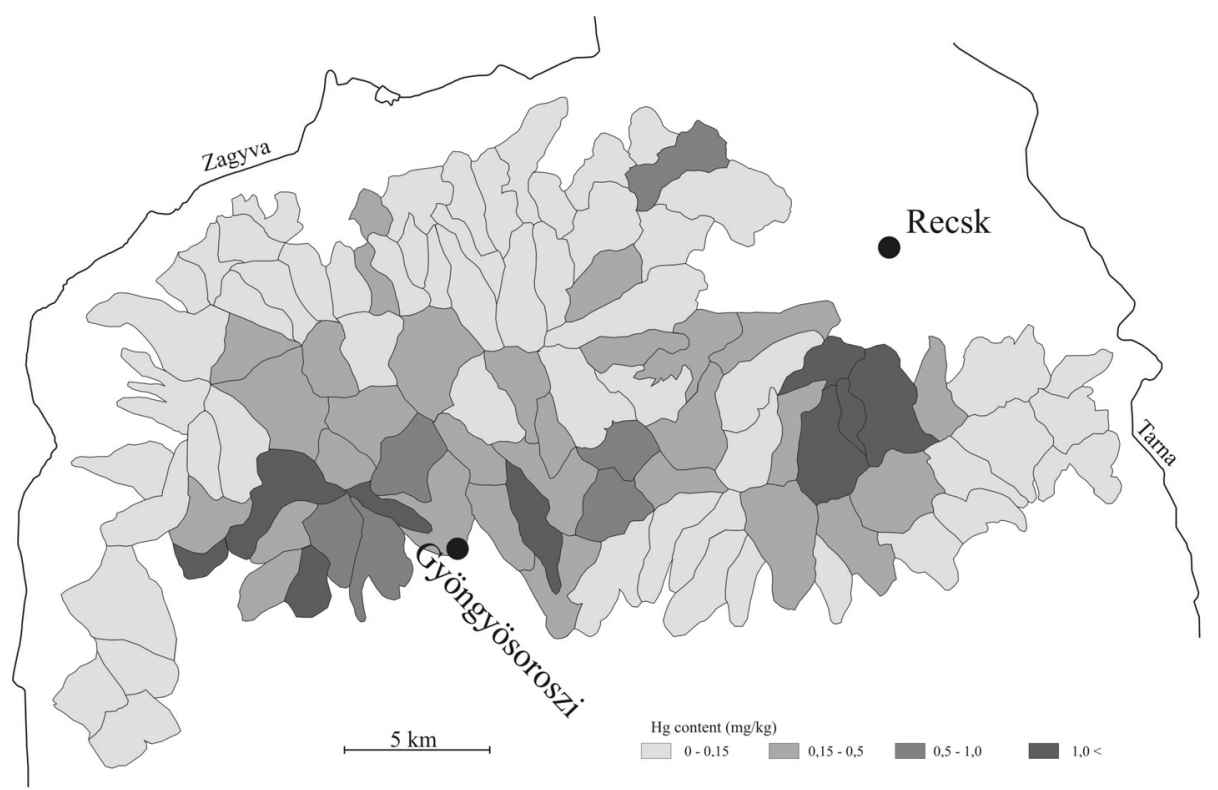

Fig. 3

Mercury concentrations in the Mátra Mountains based on stream sediment sampling

Fig. 4

Mercury concentrations in the Zemplén Mts based on stream sediment sampling



Central European Geology 52, 2009 
Table 3

Background concentrations $(\mu \mathrm{g} / \mathrm{kg})$ of mercury in the geochemical regions of Hungary (Ódor et al. 1998)

\begin{tabular}{|l|l|l|l|}
\hline Region/background & From & To & Me \\
\hline 1. & 40 & 200 & 80 \\
\hline 2. (limy) & 30 & 370 & 80 \\
\hline 3. (ferrous) & 60 & 120 & 90 \\
\hline 4. (eastern) & 80 & 750 & 140 \\
\hline
\end{tabular}

Me-median
The background levels of the mountain- and hilly regions (Table 4) are also quite close to each other and these are very similar to the subregional medians of the Geochemical Atlas of the Republic of Croatia (Halamić and Miko 2009, 35-105 $\mu \mathrm{g} / \mathrm{kg})$. It can be suggested that the smaller part of the relevant values below background level could have been due to analytical reasons (the Zemplén Mountains, Pilis-Buda Mountains, Börzsöny-Visegrád

Mountains and Cserhát Hills were sampled at the beginning of the project and analyzed with the cold vapor AAS technique).

The anomaly in Mátra (Fig. 3) is due to a number of processes, including the erosion of extensive ore zones (Gedeon et al. 1959; Gedeon 1964), environmental contamination resulting from the Gyöngyösoroszi ore mine (Fügedi 2004) and the As-Sb-Hg low-temperature hydrothermal mineralization discovered in the area of the southwestern part of the mountains (Csongrádi 1984). At the same time the background values in the Börzsöny and Zemplén Mountains (Fig. 4) are not affected by mineralization, due to its substantially smaller extent: the anomalies are separate from the background. A slight but characteristic anomaly was detected between the Visegrád and Pilis Mountains.

Table 4

Median background concentrations of mercury $(\mu \mathrm{g} / \mathrm{kg})$ in some mountanious or hilly areas of Hungary

\begin{tabular}{|l|l|l|l|}
\hline Zemplén Mts. & 28 & Börzsöny-Visegrádi Mts. & 70 \\
\hline Mecsek-Villány & 25 & Cserhát & 30 \\
\hline Bakony & 35 & Mátra & 140 \\
\hline Vértes & 50 & Heves-Borsod Hills & 40 \\
\hline Gerecse & 30 & Bükk & 90 \\
\hline Pilis-Budai Mts. & 50 & Aggtelek-Rudabánya Mts. & 80 \\
\hline
\end{tabular}




\section{Discussion}

In terms of their size mercury anomalies occurring in Hungary can be assigned to three main categories as follows.

\section{Regional level}

In the (eastern) geochemical region (No 4), beside $\mathrm{Hg}$ the precious and base metals $\mathrm{Ag}, \mathrm{Au}, \mathrm{Cd}, \mathrm{Cu}, \mathrm{Pb}$, and $\mathrm{Zn}$, as well as their accompanying elements (As, $\mathrm{Sb})$ also occur in anomalous concentrations. These anomalies do not extend throughout the entire surface of the catchment areas displayed on the map. They are restricted to the rivers' floodplains beneath heavy industrial complexes in the Transylvanian mining region and of Kazincbarcika and Košice. The contaminated sedimentary sequence is at least $60 \mathrm{~cm}$ thick; the length of the contaminated floodplains totals several hundred kilometers; their width, unmeasured, is probably in the order of one kilometer. The highest value of $\mathrm{Hg}$ detected in these sediments is $96 \mu \mathrm{g} / \mathrm{kg}$ mercury. This is still just one order of magnitude above the Clarke for $\mathrm{Hg}$.

As shown by the first results of our analyses performed within the framework of Romanian-Hungarian cooperation (Horvath et al. 2009) Hg contamination can apparently be detected from the mining area down to the mouth of the Tisza River.

\section{Subregional level}

Natural mercury anomalies occur extensively as a result of hydrothermal ore mineralization processes (Zemplén Mountains, Mátra and Börzsöny), as well as along some deep faults, like the fault zone between the Pilis and Visegrád Mountains. Their individual surface area amounts to some or some dozen $\mathrm{km}^{2}$; their intensity varies between 300 and $3000 \mu \mathrm{g} / \mathrm{kg} \mathrm{Hg}$. In some anomalies (Zemplén Mountains, Mátra and Börzsöny) mercury occurs as the accompanying element of precious and base metals. However, $\mathrm{Hg}$ alone occurs in the form of occasional scattered metacinnabarite elsewhere (Zemplén and Dunazug Mountains). These natural anomalies have occasionally been substantially enhanced and strengthened by mining activities (Telkibánya, Gyöngyösoroszi, Nagybörzsöny and Recsk-Lahóca).

\section{Local level}

The industry-induced mercury anomalies of Hungary were surveyed within the framework of NATO's ASI program (Fügedi et al. 1996). Industrial plants (Kazincbarcika, Balatonfúzfő) as well as thermal power stations have been the main emitters in the past and continue to be so today. The concentration of mercury can attain several percent in the surficial geologic sequence beneath 
electrolytic plants as well. The contamination caused by factories is so small and the signal caused by power stations is so weak that these possible sources remain undetectable at the scale of our geologic survey.

\section{Conclusions}

In Hungary, natural enrichments of mercury are the result of Neogene postvolcanic activities; they are not very significant. Substantial mercury contamination was detected only in the immediate vicinity of large mines and some major industrial complexes. Since they are found mainly in Transylvania, it would be quite reasonable to study the removal of ore minerals jointly with Rumanian colleagues. The 1:50,000 scale is still not sufficiently detailed to detect the well-known domestic contamination.

\section{Acknowledgement}

Sincere thanks are given to Clemens Reinmann for his varied help.

\section{References}

Bertalan, É., A. Bartha 1999: Analytical background of Carlin-type gold prospection in Hungary. Geologica Hungarica Ser. Geol., 24, pp. 169-178.

Csongrádi, J. 1984: Epi-teletermális Hg-Sb indikáció az Asztag-kő-Üstök-fő környékén (Epitelethermal Hg-Sb indication in the surroundings of Asztag-kő-Üstök-fô). - MÁFI Évi Jelentés 1982-ról, pp. 119-135. (In Hungarian.)

Darnley, A., A. Björklund, B. Bølviken, N. Gustavson, P.V. Koval, J.A. Plant 1995: A global geochemical database for environmental and resource management. Recommendations for international geochemical mapping. - Final Report of IGCP-Project 259, Unesco Publishing, Paris, France.

EU, 2008. European Union Risk Assessment Report Diantimony Trioxide, CAS No: 1309-64-4, Einecs No: 215-175-0. Rapporteur: Sweden. - Office for official publications of the European Communities, Luxembourg. <http://ecb.jrc.ec.europa.eu/whatsnew/>.

Fursov, V.Z. 1977: Rtuty-indikator pri geokhimicheskikh poiskakh rudnykh mestorozhdenij (Mercury indicator for the geochemical exploration of ore occurrences). - Moscow, Nedra. pp. 34-35. (In Russian.)

Fursov, V.Z. 1983: Gazortutnij metod poiskov mestorozhdenij poleznykh iskopaemykh (Gaseous mercury method used for the exploration of the occurrences of workable mineral resources). Moscow, Nauka. 205 p. (In Russian.)

Fügedi, U., L. Ódor, É. Vetô-Ákos 1995: Mercury related Environmental Problems in Hungary. NATO Advanced Research Workshop: Regional and Global Mercury Cycles: Sources, Fluxes and Mass Balances, Abstracts, 10-14 July 1995, Novosibirsk, Russia, pp. 37-38.

Fügedi, U., A. Moyzes, L. Ódor, É. Vető-Ákos 1996: Case studies on mercury related environmental problems in Hungary. - In: Baeyens, W., R. Ebinghaus, O. Vasiliev (Eds): Regional and Global Mercury Cycles: Sources, Fluxes and Mass Balances. Kluwer Academic Publishers, Dordrecht, The Netherlands, pp. 491-498.

Fügedi, U. 2004: Geokémiai háttér és nehézfémszennyezés Gyöngyösoroszi térségében (Geochemical background and heavy metal pollution in the environs of Gyöngyösoroszi). Földtani Közlöny, 134/2, pp. 291-301. (In Hungarian with English abstract.) 
Fügedi, U., I. Horváth, L. Odor 2006: Geokémiai háttér és a természetes eredetú környezeti terhelés Magyarország felszíni képződményeiben (The geochemical background and natural environmental impact in the near-surface geological formations of Hungary). - In: Szendrei, G. (Ed.): Magyarország környezetgeokémiai állapota, 11-21. MTA, Budapest. (In Hungarian.)

Fügedi, U., I. Horváth, L. Ódor 2007: Geokémiai háttérértékek Magyarország hegyvidéki területein (Geochemical background values in the mountain regions of Hungary). - Földtani Közlöny, 137/1, pp. 63-74. (In Hungarian with English abstract.)

Gedeon, A. 1964: Geokémiai mérések a Mátrahegységben, 1962 (Geochemical measurements in the Mátra Mountains, 1962). - MÁFI Évi Jelentése 1962-ről, pp. 337-346. (In Hungarian.)

Gedeon, A., B. Kovács B., A. Vidacs 1959: Hidrokémiai és metallometriai felvételek a Mátrában ([Hydrochemical and metallometric surveys in the Mátra, 1956-1958.). - MÁELGI Jelentése 1958-ról. (In Hungarian.)

Halamic, J., S. Miko (Eds.) 2009: Geochemical Atlas of the Republic of Croatia. Zagreb, HGI.

Hartikainen, A., I. Horváth, L. Ódor, L.Ó Kovács, J. Csongrádi 1992: Regional multimedia geochemical exploration for $\mathrm{Au}$ in the Tokaj Mountains, northeast Hungary. - Applied Geochemistry, 7, pp. 533-547.

Horvath, E., G. Jordan, U. Fugedi, A. Bartha, L. Kuti, G. Heltai, J. Kalmár, I. Waldmann, I. Napradean, G. Damian 2009: Risk Assessment of Heavy Metals in Abandoned Mine Lands as Significant Contamination Problem in Romania. - Geophysical Research, Abstracts Vol. 11, EGU2009-0. EGU General Assembly.

Magak'jan, I.G. 1974: Metallogenija (Metallogeny) - Moscow, Nedra. 304 p. (In Russian.)

Mach, C.E., S. Peterson, N.S. Bloom 1996: Mercury contamination and speciation in the Carson River and Lahontan Reservoir. - In: Ebinghaus, R., G. Petersen, U. von Tümpling 1996: 4th International Conference on Mercury as a Global Pollutant August 4-8, 1996. Book of Abstracts, p. 142.

Ódor, L., I. Horváth, U. Fügedi 1997: Low-density geochemical mapping in Hungary. - Journal of Geochemical Exploration, 60, pp. 55-66.

Ódor, L., I. Horváth, U. Fügedi 1998: Magyarország geokémiai atlasza (The geochemical atlas of Hungary). - http://www.mafi.hu/geokem/Fomenu.html. (In Hungarian.)

Ódor, L., R.B. Wanty, I. Horváth, U. Fügedi 1999: Environmental signatures of mineral deposits and areas of regional hydrothermal alteration in Northeastern Hungary. - Geologica Hungarica, Ser. Geol., 24, pp. 107-129.

Ping, Li, Xinbin Feng, Lihai Shang, Guangle Qiu, Bo Meng, Peng Liang, Hua Zhang 2008: Mercury pollution from artisanal mercury mining in Tongren, Guizhou, China. - Applied Geochemistry, 23/8, pp. 2055-2064.

Reimann, C., R.G. Garrett 2005: Geochemical background - concept and reality. - Sci. Total Environ., 350, pp. $12-27$.

Reimann, C., R.G. Garrett, P. Filzmoser 2005: Background and threshold - critical comparison of methods of determination. - Sci. Total Environ., 346, pp. 1-16.

Risher, J.F. 2003: Elemental mercury and inorganic mercury compounds: human health aspects. World Health Organisation, Geneva. http://www.who.int/ipcs/publications/cicad/en/cicad50.pdf

Salminen, R., A. Demetriades, S. Reeder 2005: Introduction. - In: Salminen, R. (Chief-editor): Geochemical atlas of Europe. Part 1. Background information, methodology and maps. Geological Survey of Finland, Espoo 2005.

Sandström, H., S. Reeder, A. Bartha, M. Birke, F. Berge, B. Davidsen, A. Grimstvedt, M-L. HagelBrunnström, W. Kantor, E. Kallio, G. Klaver, P. Lucivjansky, D. Mackovych, H. Mjartanova, B van Os, P. Paslawski, E. Popiolek, U. Siewers, Zs. Varga-Barna, E. van Vilsteren, M. Ødegård 2005: Sample Preparation and Analysis. - In: Salminen, R. (Chief-editor): Geochemical atlas of Europe. Part 1. Background information, methodology and maps. Geological Survey of Finland, Espoo, 2005. 
Saukov, A.A. 1946: Geokhimija rtuti (The geochemistry of mercury). - Moscow, Tr. AN SzSzSzR, Min. Geokh. Ser. 17. (In Russian.)

Sergeev, E.A. 1957: Metodika rtutometricheskikh issledovanij. - In: Geokhimicheszkie metody poiskov rudnykh mestorozhdenij v SSSR. (Methodology of mercury-metric investigations. In: Geochemical methods of the exploration of ore occurrences is SU). Moscow. p. 158-165. (In Russian.)

Smith, J.E., A.M. Smith (eds) 1972: Minamata: a warning to the world. - London, Chatto \& Windus. $192 \mathrm{p}$.

Weaver, T.A., D.E. Broxton, S.L. Bolivar, S.H. Freeman 1983: The Geochemical Atlas of Alaska. Geochemical Group, Earth and Space Sciences Division, Los Alamos.

WebElements 2010: the periodic table on the web. (2010.04.07.) http://www.webelements.com/mercury/geology.html

Wedepohl, K.H. 1995: The composition of the continental crust. - Geochim. Cosmochim. Acta, 59, pp. 1217-1232.

Yanin, E.P. 1997: Mercury in Surroundings of the city of Temirtau, Central Kazakhstan. - Russian Academy of Sciences, Moscow. $30 \mathrm{p}$.

10/2000. (VI. 2.) KöM-EüM-FVM-KHVM együttes rendelet a felszín alatti víz és a földtani közeg minőségi védelméhez szükséges határértékekről (Unified Order No. 10/2000 of Environmental, Health, Agricultural and Land Development and Communication and Water Ministries about the limit valors required of the preservation of subsurface water and geological environment). - Hungarian Official Bulletin, June 2000, p. 2.

219/2004. (VII. 21.) Korm. rendelet a felszín alatti vizek védelméről (Unified Order No. 219/2004 of the Protection of the Ground Waters). - Hungarian Official Bulletin, 2004. 